\title{
Pengaruh pembelajaran daring dalam mengatasi kesulitan belajar
} siswa

\author{
Sifa Fauziah ${ }^{1 *}$, Miskanik Miskanik²), Veno Dwi Krisnanda ${ }^{3)}$ \\ 1,2,3) Universitas Indraprasta PGRI \\ *) sifa.fauziah1010@gmail.com
}

Article History:

Received: 03/08/2021;

Revised: 19/10/2021;

Accepted: 22/10/2021

Published: 30/10/2021.

How to cite

Fauziah, S., Miskanik, M., \& Krisnanda, V.D. (2021). Pengaruh pembelajaran daring dalam mengatasi kesulitan belajar siswa. Orien: Cakrawala Ilmiah Mahasiswa, 1(2), pp. 149156. DOI:

10.30998/ocim.v1i2.5730

(c) 1 This is an open
distributed under the Creative
Commons 4.0 Attribution
License, which permits
unrestricted use, distribution,
and reproduction in any
medium, provided the original
work is properly cited. @ 2021,
Fauziah, Miskanik, \&
Krisnanda.

Krisnanda.

\begin{abstract}
Abstrak: tujuan penelitian ini untuk mengetahui pengaruh pembelajaran daring dalam mengatasi kesulitan belajar siswa. Metode penelitian yang digunakan dalam penelitian ini adalah pendekatan kuantitatif dengan metode penelitian korelasional. Sampel dalam penelitian ini sebanyak 105 siswa dengan menggunakan simple random sampling. Instrumen yang digunakan yaitu angket pembelajaran daring dan kesulitan belajar sebanyak 32 butir angket dengan menggunakan model skala Likert. Hasil analisis data perhitungan menggunakan SPSS peneliti mendapatkan nilai korelasi sebesar 0,409 dan diperoleh koefisien sebesar 0,167 yang mengandung pengertian bahwa pengaruh variabel pembelajaran daring dalam mengatasi kesulitan belajar siswa kelas XI SMA Islam As-Syafi'iyah 01 Jakarta adalah sebesar 16,7\% atau dapat dikatakan berpengaruh antara pembelajaran daring dalam mengatasi kesulitan belajar siswa. Hasil penelitian ini berguna untuk sekolah dalam melakukan pembelajaran daring agar lebih efektif guna membantu mengembangkan potensi dan mengentaskan permasalahan siswa.
\end{abstract}

Kata Kunci: pembelajaran daring, kesulitan belajar

Abstract: the purpose of this study was to determine the effect of online learning in overcoming students' learning difficulties. The research method used in this study is a quantitative approach with correlational research methods. The sample in this study was 105 students using simple random sampling. The instrument used is an online learning questionnaire and learning difficulties as many as 32 questionnaire items using a Likert scale model. The results of the calculation data analysis using SPSS researchers get a correlation value of 0.409 and a coefficient of 0.167 is obtained which implies that the influence of online learning variables in overcoming learning difficulties for class XI students of SMA Islam As-Syafi'iyah 01 Jakarta is $16.7 \%$ or it can be said influence between online learning in overcoming students' learning difficulties. The results of this study are useful for schools in conducting online learning to be more effective in order to help develop potential and alleviate student problems.

Keywords: online learning, learning difficultiess

\section{Pendahuluan}

Dunia digemparkan dengan adanya Covid-19 (Coronavirus Disease-2019) pada penghujung 2019, virus ini dilaporkan pertama kali di Wuhan, China dan telah melanda lebih dari 200 Negara di dunia termasuk Indonesia, gejala yang paling umum dirasakan adalah demam, batuk kering dan kelelahan, virus ini dapat menyebar melalui percikan cairan yang berasal dari saluran pernafasan atau mulut. Wabah ini telah memberikan tantangan tersendiri 
bagi berbagai aspek termasuk lembaga pendidikan, untuk mengantisipasi penularan virus tersebut pemerintah telah mengeluarkan berbagai kebijakan, seperti isolasi mandiri, social and physical distancing hingga pembatasan sosial berskala besar (PSBB).

Pemerintah Indonesia melalui Kementerian Pendidikan dan Kebudayaan dan Kementerian Agama Republik Indonesia menerapkan kebijakan kepada masyarakat untuk belajar dan bekerja dari rumah (Work from Home) mulai pertengahan Maret 2020. Wabah Covid19 ini mengharuskan warga untuk tetap berada di rumah untuk melakukan berbagai kegiatan baik itu bekerja, maupun beribadah dan juga sekolah. Kondisi saat ini menuntut pendidik untuk terus berinovasi mengubah pola pembelajaran tatap muka menjadi pola pembelajaran tanpa tatap muka atau yang dikenal dengan sebutan daring.

Pembelajaran daring merupakan solusi dalam membantu pemerintah mengatasi adanya situasi wabah Covid-19 ini, karena pembelajaran daring merupakan proses pembelajaran yang menggunakan sistem komunikasi jarak jauh dengan bantuan jaringan internet tanpa adanya tatap muka secara langsung. Proses Pembelajaran daring yang sangat dibutuhkan yaitu memaksimalkan interaksi antar siswa serta tenaga pengajar atau guru tanpa menghilangkan prinsip pembelajaran.

Proses pembelajaran daring ini sebetulnya dapat dilaksanakan dengan baik jika sarana dan prasarana siswa dan guru terpenuhi dengan merata, dalam pembelajaran daring siswa dan guru memerlukan perangkat yang dapat menunjang pembelajaran supaya berjalan dengan baik dan efektif, dimulai dari jaringan internet, laptop atau komputer dan smartphone yang wajib digunakan untuk pembelajaran daring. Kendala yang dihadapi dalam penerapan pembelajaran daring ini yaitu kemampuan siswa dan orang tua dalam menyediakan fasilitas yang dibutuhkannya, kemampuan guru dalam membuat pembelajaran daring menjadi lebih efektif dan masalah jaringan internet yang tidak merata di semua tempat.

Pembelajaran daring yang dihadapi menjadi kendala dan tantangan tersendiri bagi guru. Guru sangat berpengaruh dalam proses pembelajaran daring dalam mengatasi berbagai kendala yang dihadapi dengan memaksimalkan sumber daya yang ada dan membuat rancangan pembelajaran yang mudah diakses oleh siswa supaya memudahkan siswa dalam belajar serta memahami materi yang diberikan oleh guru. Belajar yang dialami siswa merupakan proses yang digunakan dalam memperoleh hasil belajar. Hasil belajar termasuk salah satu komponen penting dalam proses belajar, karena hasil belajar merupakan tolak ukur dari keberhasilan pembelajaran yang sudah dilakukan oleh siswa di sekolah. Kegiatan belajar siswa di sekolah pada dasarnya tidak selalu berjalan dengan apa yang diharapkan, terkadang siswa juga mengalami hambatan atau kesulitan belajar. Siswa dapat diduga mengalami kesulitan belajar jika yang bersangkutan menunjukan kegagalan tertentu dalam mencapai tujuan-tujuan belajarnya.

Kesulitan belajar yang dialami siswa secara terus menerus atau menetap tanpa adanya perhatian dari guru maupun keluarga dan pihak yang lainnya akan berdampak pada ketertinggalan siswa terhadap materi pembelajaran yang diberikan, sehingga siswa merasa malas dalam mengejar ketertinggalannya karena sudah terlalu banyaknya informasi atau materi yang harus dikuasai. Karakter dan kemampuan belajar siswa yang berbeda-beda merupakan tugas guru dalam mengenali dan mengetahui potensi siswa yang mengalami kesulitan belajar. Kondisi tersebut terdapat siswa yang mampu menyelesaikan kesulitan belajarnya sendiri, tetapi ada pula siswa yang membutuhkan bantuan orang lain dalam menyelesaikan kesulitan belajarnya. Guru profesional seharusnya mampu mengetahui tingkat pemahaman siswa dalam belajar supaya meminimalisir adanya kesulitan belajar yang terjadi pada diri siswa. Gejala adanya kesulitan belajar pada siswa yaitu, prestasi belajar yang rendah, terdapat siswa yang lambat dalam mengerjakan tugas-tugas belajar, dan juga terdapat siswa yang menunjukkan 
sikap kurang wajar. Kesulitan belajar pada dasarnya tidak selalu disebabkan oleh siswa yang malas belajar dan kemampuan intelektual siswa yang rendah, tetapi perhatian dan dorongan dari Lingkungan sekitar juga diperlukan termasuk guru, orang tua, teman bergaul dan pihak lainnya.

Kesulitan belajar merupakan keadaan dimana siswa tidak dapat belajar sebagaimana mestinya. Macam-macam kesulitan belajar dapat dikelompokkan menjadi empat macam dilihat dari 1) jenis kesulitan belajar, ada yang berat dan ada yang sedang; 2) bidang studi yang dipelajari, ada yang sebagian bidang studi dan ada yang keseluruhan bidang studi; 3) sifat kesulitannya, ada yang sifatnya permanen/menetap dan ada yang sifatnya hanya sementara; dan 4) faktor penyebabnya, ada yang karena faktor intelegensi dan ada yang karena faktor non inteligensi (Dalyono, 2015).

Perkembangan teknologi memberikan pengaruh yang sangat besar terhadap perubahan dalam setiap bidang. Teknologi dapat dimanfaatkan dalam situasi wabah Covid-19 yang terjadi saat ini untuk berbagai kegiatan seperti proses belajar mengajar yang dapat dikatakan merupakan pergantian dari cara konvensional menjadi ke modern, salah satunya ialah perubahan pada bidang pendidikan. Solusi yang dapat dilakukan siswa untuk mengatasi kesulitan belajar selama proses pembelajaran daring salah satunya yaitu siswa dapat menggunakan media lain sebagai media pembelajaran seperti video yang dapat diakses melalui youtobe atau platfrom lainnya yang dapat menyediakan materi belajar yang terpercaya, siswa juga dapat melakukan pembelajaran daring dengan cara berlatih mengerjakan beberapa soal latihan sesuai dengan materi yang sudah diajarkan oleh guru.

Tujuan dari penelitian ini adalah untuk mencari tahu adakah pengaruh pembelajaran daring dalam mengatasi kesulitan belajar siswa kelas XI SMA Islam As'syafiiyah 01 Jakarta dan juga membuktikan hipotesis atau dugaan sementara yang telah peneliti buat bahwa terdapat pengaruh pembelajaran daring dalam mengatasi kesulitan belajar siswa kelas XI SMA Islam AsSyafi'iyah 01 Jakarta.

\section{Metode}

Jenis penelitian ini adalah penelitian dengan pendekatan kuantitatif yang bersifat noneksperimental, dengan metode korelasional. Populasi dalam penelitian ini adalah seluruh siswa kelas XI SMA Islam As-Syafi'iyah 01 Jakarta yang berjumlah 143 orang yang terdiri dari 4 (empat) kelas, yaitu XI MIPA 1, XI MIPA 2, XI IPS 1, XI IPS 2. Teknik pengambilan sampel pada penelitian ini menggunakan pengambilan simple random sampling, apabila semua anggota populasi diberikan kesempatan yang sama untuk dipilih sebagai sampel penelitian. Perhitungan menggunakan rumus Slovin, dengan tingkat kesalahan sebesar 0,05. Berdasarkan rumus Slovin tersebut, maka peneliti mengambil sampel dalam penelitian sebanyak 105 siswa kelas XI SMA Islam As-Syafi'iyah 01 Jakarta. Instrumen penelitian yang digunakan dalam penelitian ini yaitu angket kuesioner yang terdiri dari 32 butir pernyataan.

Penelitian ini dilaksanakan kurang lebih selama 9 bulan, terhitung dari bulan Desember 2020 hingga Agustus 2021 dengan berbagai tahapan-tahapan. Mulai tahap persiapan, tahap pengumpulan data dan tahap analisis data. Pengolahan analisis data ini menggunakan uji lineritas bertujuan untuk mengetahui apakah data dua variabel mempunyai hubungan yang linear atau tidak secara signifikan, Uji regresi linear sederhana untuk mengetahui sejauh mana hubungan sebab akibat antara variabel independen terhadap variabel dependen, uji $t$ untuk menunjukkan seberapa jauh pengaruh antara variabel independen dengan variabel dependen dan uji koefisieen determinasi untuk mengetahui seberapa besar pengaruh pembelajaran daring dalam mengatasi kesulitan belajar. 


\section{Hasil dan Diskusi}

Dari hasil analisis penelitian yang dilakukan berdasarkan data yang ada, yaitu pembelajaran daring merupakan upaya untuk menekan angka pandemi Covid-19 yang digunakan oleh pihak sekolah dalam memberikan pembelajaran kepada siswa, serta siswa dapat melakukan pembelajaran dengan semestinya, meskipun dalam pembelajaran daring pasti ditemukan hambatan-hambatan yang terjadi pada siswa, berbagai pihak dapat bekerjasama dalam mengatasi hambatan-hambatan atau kesulitan yang dialami, supaya siswa dapat melakukan pembelajaran yang efektif dan mendapatkan hasil yang maksimal sesuai yang diharapkan. Salah satu dari tujuan penelitian ini adalah untuk mengetahui adakah pengaruh pembelajaran daring dalam mengatasi kesulitan belajar siswa, setelah melakukan penyebaran instrument penelitian dan melakukan analisis data dengan menggunakan uji analisis regresi sederhana.

Tabel 1. Uji Linearitas

\begin{tabular}{|c|c|c|c|c|c|c|c|}
\hline \multicolumn{8}{|c|}{ ANOVA Table } \\
\hline & & & Sum of Squares & $d f$ & $\begin{array}{l}\text { Mean } \\
\text { Square }\end{array}$ & $F$ & Sig \\
\hline \multirow{5}{*}{$\begin{array}{l}\text { Kesulitan belajar* } \\
\text { pembelajaran } \\
\text { daring }\end{array}$} & & (Combined) & 1595.016 & 16 & 99.688 & 2.070 & .017 \\
\hline & Between Groups & Linearity & 976.794 & 1 & 976.794 & 20.281 & .000 \\
\hline & & Deviation From & 618.222 & 15 & 41.215 & .856 & .614 \\
\hline & Within Groups & Linearity & 4238.375 & 88 & 48.163 & & \\
\hline & Total & & 5833.390 & 104 & & & \\
\hline
\end{tabular}

Sumber: Output SPSS

Berdasarkan hasil uji linearitas pada tabel 1, diketahui nilai signifikan sebesar 0,614 >0,05 maka dapat disimpulkan bahwa terdapat hubungan yang linear antara pengaruh pembelajaran daring dalam mengatasi kesulitan belajar siswa.

Tabel 2. Hasil Uji Regresi Linear Sederhana

ANOVA

\begin{tabular}{ccccccc}
\hline & Model & Sum of Squares & $d f$ & Mean Square & $F$ & Sig \\
\hline 1 & Regression & 976.794 & 1 & 976.794 & 20.716 & $.000^{\mathrm{a}}$ \\
& Residual & 4856.596 & 103 & 47.151 & & \\
Total & 5833.390 & 104 & & & \\
\hline
\end{tabular}

a. Predictors: (Constant), Pembelajaran Daring

b. Dependent Variable: Kesulitan Belajar

Sumber: Output SPSS

Berdasarkan hasil uji regresi sederhana peneliti mendapatkan bahwa nilai Fhitung $=20,716$ dengan tingkat signifikansi sebesar 0,000 <0,05, maka model regresi dapat dipakai untuk memprediksi variabel pembelajaran daring atau dengan kata lain ada pengaruh variabel pembelajaran daring $(X)$ dalam mengatasi variabel kesulitan belajar $(Y)$. 
Tabel 3. Hasil Uji t

Coefficients $^{\mathrm{a}}$

\begin{tabular}{|c|c|c|c|c|c|c|}
\hline \multirow{2}{*}{\multicolumn{2}{|c|}{ Model }} & \multicolumn{2}{|c|}{ Unstandarized Coefficients } & \multirow{2}{*}{$\begin{array}{c}\text { Unstandarized Coefficients } \\
\text { Betta }\end{array}$} & \multirow[t]{2}{*}{$\mathrm{t}$} & \multirow[t]{2}{*}{ Sig } \\
\hline & & $B$ & Std. Error & & & \\
\hline \multirow[t]{2}{*}{1} & (Constant) & 21.057 & 7.389 & & 2.846 & .005 \\
\hline & Pembelajaran daring & .820 & 180 & .409 & 4.551 & .000 \\
\hline
\end{tabular}

a. Predictors: (Constant), pembelajaran daring

Sumber: Output SPSS

Berdasarkan tabel 3 diketahui bahwa nilai thitung sebesar 4,551 lebih besar dari nilai tabel 1,98326 dengan nilai signifikansi 0,000 $<0,05$ maka dari hasil tersebut dapat disimpulkan bahwa pembelajaran daring berpengaruh positif dan signifikan dalam mengatasi kesulitan belajar siswa karena nilai thitung $>$ tabel dan nilai signifikan lebih kecil dari 0,05 sehingga $H_{o}$ ditolak dan $H_{a}$ diterima. Sehingga hal ini menunjukkan bahwa pembelajaran daring berpengaruh positif dan signifikan dalam mengatasi kesulitan belajar siswa.

Tabel 4. Hasil Uji t

Coefficients $^{\mathrm{a}}$

\begin{tabular}{ccccc}
\hline Model & $\mathrm{R}$ & $\mathrm{R}$ Square & Adjusted R Square & Std. Error of the Estimate \\
\hline 1 & $.409^{\mathrm{a}}$ & .167 & .159 & 6.867 \\
\hline
\end{tabular}

a. Dependent Variable: kesulitan Belajar

Sumber: Output SPSS

Berdasarkan pada tabel 4 di atas, hasil perhitungan menggunakan SPSS peneliti mendapatkan nilai korelasi (R) sebesar 0,409 dan diperoleh koefisien (R square) sebesar 0,167 yang mengandung pengertian bahwa pengaruh variabel pembelajaran daring dalam mengatasi kesulitan belajar siswa kelas XI adalah sebesar 16,7\% atau dapat dikatakan berpengaruh antara pembelajaran daring dalam mengatasi kesulitan belajar siswa.

Hasil penelitian ini secara teknis dapat dijadikan dasar dalam pengembangan penelitian lanjutan bagi penelitian yang berkaitan dengan pembelajaran daring dan kesulitan belajar siswa. Penelitian ini juga dapat dilakukan atau diterapkan pada pihak yang bersangkutan seperti kepala sekolah dan guru untuk mengetahui mengenai pembelajaran daring dan kesulitan belajar siswa sehingga dapat membangun pembelajaran daring yang efektif.

Peneliti menyadari bahwa penelitian ini belum sempurna, dan memiliki keterbatasan diantarnya yaitu hasil penelitian ini belum tentu dapat di generalisasikan kepada sekolah lainnya, karena setiap individu tentu memiliki pernyataan yang berlainan. Peneliti yang akan meneliti mengenai pembelajaran daring dalam mengatasi kesulitan belajar siswa, hendaknya mempersiapkan alat pengumpulan data yang lebih rinci lagi dan mencari faktor-faktor lain. Disarankan untuk menggunakan metode lain seperti metode penelitian eksperimen kepada siswa.

\section{Simpulan}

Berdasarkan hasil penelitian dan pembahasan yang peneliti lakukan tentang "Pengaruh Pembelajaran Daring dalam Mengatasi Kesulitan Belajar Siswa Kelas XI SMA Islam As'syafiiyah 01 Jakarta" bahwasanya perdapat pengaruh signifikan pemebelajaran daring (X) dalam 
mengatasi kesulitan belajar siswa (Y) di SMA Islam As-Syafi'iyah 01 Jakarta. Semakin baik pembelajaran daring yang diberikan kepada siswa maka akan semakin baik pula siswa dalam mengatasi kesulitan belajar di SMA Islam As-Syafi'iyah 01 Jakarta.

\section{Ucapan Terima Kasih}

Terimakasih peneliti ucapkan kepada berbagai pihak yang telah membantu dalam menyelesaikan penelitian ini, yang merupakan salah satu syarat untuk mendapatkan gelar sarjana. Terimakasih kepada Dosen Pembimbing Materi dan Dosen pembimbing Teknik, serta para Dosen lainnya yang selama 4 (empat) tahun telah memberikan ilmunya. Terimakasih kepada orang tua dan keluarga telah menjadi support system bagi peneliti dan tentunya temanteman yang terus memberikan dukungan sehingga peneliti berhasil menyelesaikan penelitian ini.

\section{Daftar Rujukan}

Atieka,N. (2016). Upaya Mengatasi Kesulitan Belajar Siswa Melalui Layanan Bimbingan Kelompok Di SMP Negeri 2 Sungkai Utara Lampung Utara. Jurnal Lentera Pendidikan LPPM UM METRO. 1(1)hlm. 91-99

Andayani, N, dkk. (2014). Penerapan Layanan Bimbingan Belajar untuk Meningkatkan Prestasi Belajar Bagi Siswa yang Mengalami Kesulitan Belajar Siswa Kelas X4 SMA Negeri 1 Sukasada. Jurnal Undiksa Jurusan Bimbingan Konseling. 2(1)hlm. 1-10

Anugrahana,A. dkk. (2020). Hambatan, Solusi dan Harapan: Pembelajaran Daring Selama Masa Pandemi Covid-19 Oleh Guru Sekolah Dasar. Jurnal Pendidikan dan Kebudayaan. 10(3)hlm. 282-289

Amalia, E. (2021). Analisis Kesulitan Belajar Siswa Pada Mata Pelajaran Matematika Melalui Sistem Pembelajaran Daring Di Sekolah Menengah Pertama Negeri 08 Kota Lubuklinggau. (Skripsi). Program Studi Tadris Matematika Fakultas Tarbiyah dan Keguruan, Universitas Islam Negeri Sultan Thaha Saifuddin, Jambi.

Burton H. W. (1952) The Guidance of Learning Activities. N.Y. Appleton CenturyCraffts. Inc.

Chairudin, A. (2020). Pengaruh Pembelajaran Online Terhadap Prestasi Siswa Kelas 5 Dan 6 Mi Ma'arif Gedangan, Kec Tuntang, Kab Semarang Tahun Ajaran 2020/2021. (Skripsi). Program Studi Pendidikan Guru Madrasah Ibtidaiyah Fakultas Tarbiyah Dan Ilmu Keguruan, Institut Agama Islam Negeri (IAIN), Salatiga.

Dalyono, M. (2015). Psikologi Pendidikan. Edisi 8 Jakarta : Rineka Cipta

Dewantara, J, dkk. (2021). Efektivitas Pembelajaran Daring di Masa Pandemi COVID 19 Bagi Mahasiswa Universitas PGRI Yogyakarta. Jurnal Basicedu. 5(1)hlm.367-375

Fitriyani,I,dkk (2020). Analisis Biaya Modal Terhadap Tingkat Pengembalian Investasi Pada PT. Mitra Adiprakasa, Tbk. Jurnal Akuntansi dan Keuangan.7(2)hlm. 192-197 
Fauza, N,dkk. (2020). Difficulty Analysis Of Physics Students In Learning Online During Pandemic Covid-19. Jurnal Geliga Sains Pendidikan Fisika. 8(1) hlm.49-55

Firmansyah, M. (2017). Analisis Hambatan Belajar Mahasiswa Pada Mata Kuliah Statistika. Jurnal. 10(2)hlm.115-127

Handarini, O, dkk. (2020). Pembelajaran Daring Sebagai Upaya Study From Home (SFH) Selama Pandemi Covid 19. Jurnal Pendidikan Administrasi Perkantoran (JPAP). 8(3)hlm. 496-503

Ilyas, A, dkk. (2017). Diagnosis Kesulitan Belajar E Pembelajaran Remedial. Semarang: Jurusan Bimbingan dan Konseling Fakultas Ilmu Pendidikan Universitas Negeri Semarang.

Mustofa, M, dkk. (2019). Formulasi Model Perkuliahan Daring Sebagai Upaya Menekan Disparitas Kualitas Perguruan Tinggi. Walisongo Journal of Information Technology. 1 (2)hlm.151-160

M,Alisuf. (1995). Psikologi Pendidikan. Jakarta : Pedoman Ilmu Jaya.

Mauliza,P. (2020). Pengaruh Pengawasan, Disiplin Kerja Terhadap Kinerja Pegawai di Dinas Pendidikan Kota Banda Aceh. Jurnal Ekonomi, Manajemen, dan Akuntansi. 6(2)hlm. 71-81

Nisa, A. (2017)." Peranan Bimbingan Dan Konseling Dalam Membantu Mengatasi Masalah Kesulitan Belajar Siswa. Jurnal Bimbingan dan Konseling. 1(2)hlm.1-11

Putria,H,dkk. (2020). Analisis Proses Pembelajaran Dalam Jaringan (DARING) Masa Pandemi COVID-19 pada Guru Sekolah Dasar. Jurnal Basicedu. 4(4)hlm.861-872

Partowisastro dan Hadisuparto. (1998). Diagnosis dan Pemecahan Kesulitan Belajar : Jilid 1. Jakarta : Erlangga.

Syarifudin, A. (2020). Impelementasi Pembelajaran Daring Untuk Meningkatkan Mutu Pendidikan Sebagai Dampak Diterapkannya Social Distancing. Jurnal Pendidikan Bahasa dan Sastra Indonesia. 5(1)hlm.31-34

Sena, W. (2020). Analisis Kesulitan Siswa Dalam Pembelajaran Daring Materi Statistika Mata Pelajaran Matematika Pada Mts Negeri Di Grobogan. (Skripsi). Program Studi Tadris Matematika Fakultas Tarbiyah dan Ilmu Keguruan, Institut Agama Islam Negeri (IAIN), Salatiga.

Sugiyono. (2016). Metode Penelitian Pendidikan. Bandung : Alfabeta

Wijaya, Cece. (2007). Pendidikan Remedial. Bandung: PT Remaja Rosdakarya

Yanti,M,dkk. (2020). Pemanfaatan Portal Rumah Belajar Kemendikbud Sebagai Model Pembelajaran Daring Di Sekolah Dasar. Jurnal Pendidikan Dasar Fakultas Dharma Acarya Institut Hindu Dharma Negeri Denpasar. 5(1)hlm. 61-68 
156 Pengaruh pembelajaran daring dalam mengatasi kesulitan belajar siswa

\section{Competing interests:}

The authors declare that they have no significant competing financial, professional or personal interests that might have influenced the performance or presentation of the work described in this manuscript. 